\title{
The Molecular Structure of 1,2:5,6-Di-O-isopropylidene-3-O- toluenesulfonyl- $\alpha-D$-glucofuranose
}

\section{Constantin Mamat ${ }^{1, *}$, Tim Peppel ${ }^{2}$ and Martin Köckerling ${ }^{3}$}

1 Institut für Radiopharmazie, Helmholtz-Zentrum Dresden-Rossendorf, Bautzner Landstraße 400, D-01328 Dresden, Germany

2 Leibniz Institut für Katalyse e.V. an der Universität Rostock, Albert-Einstein-Straße 29a, D-18059 Rostock, Germany; E-Mail: tim.peppel@catalysis.de

3 Institut für Chemie, Anorganische Festkörperchemie, Albert-Einstein-Straße 3a, D-18059 Rostock, Germany; E-Mail: Martin.Koeckerling@uni-rostock.de

* Author to whom correspondence should be addressed; E-Mail: c.mamat@hzdr.de; Tel.: +49-351-260 2805; Fax: +49-351-260 3232.

Received: 5 December 2011; in revised form: 16 February 2012 / Accepted: 20 February 2012 / Published: 29 February 2012

\begin{abstract}
The crystal and molecular structure of 1,2:5,6-di- $O$-isopropylidene-3- $O$ toluenesulfonyl- $\alpha$-D-glucofuranose is reported. This compound crystallizes from a petroleum ether/ethyl acetate mixture with the chiral orthorhombic space group P $2{ }_{1} 2{ }_{1} 2_{1}$ with four molecules in the unit cell. The unit cell parameters are: $a=9.7945(7) \AA$, $b=10.1945(7) \AA, c=21.306(1) \AA$, and $V=2127.4(2) \AA^{3}$. No classical hydrogen bonds were found. Bond lengths and angles of this tosylated glucofuranose derivative are typical.
\end{abstract}

Keywords: carbohydrates; glucose; tosylation

\section{Introduction}

Monosaccharides with good leaving groups like mesylate, tosylate or nosylate play a major role for the introduction of various functional groups, as building blocks for the formation of di- and oligosugars, as chiral pool materials or for the preparation of bioactive glycoconjugates [1]. This offers the possibility for the preparation of rare carbohydrate derivatives. For this purpose, protected carbohydrate building blocks like carbohydrate 2 were prepared from D-glucose (1) with the potential for the convenient selective introduction of sulfonate leaving groups in high yields under mild basic 
conditions. Thus, D-glucose (1) is protected with two isopropylidene moieties in the first step [2]. Next, the introduction of the tosylate leaving group occurs under basic conditions [3]. Interestingly, in subsequent reactions the replacement of the tosyl leaving group against the resulting functional group proceeds under inversion of the configuration of the respective carbon atom C-3 (Walden-inversion) in most of the cases [4]. In addition, side reactions like eliminations were observed as well [5].

\section{Results and Discussion}

The introduction of isopropylidene protecting groups under acid catalysis occurs chemoselectively and the 1,2:5,6-diisopropylidene- $\alpha$-D-glucose (2) as furanose form was prepared in high yields [2]. Treatment of glucose 2 with $p$-TsCl in the presence of pyridine as base afforded the desired carbohydrate building block 3 in a high yield of 78\% (Figure 1). Crystals of 3 were grown during the purification step from a saturated petroleum ether/ethyl acetate solution.

Figure 1. The synthesis of tosylated glucose derivative 3 .

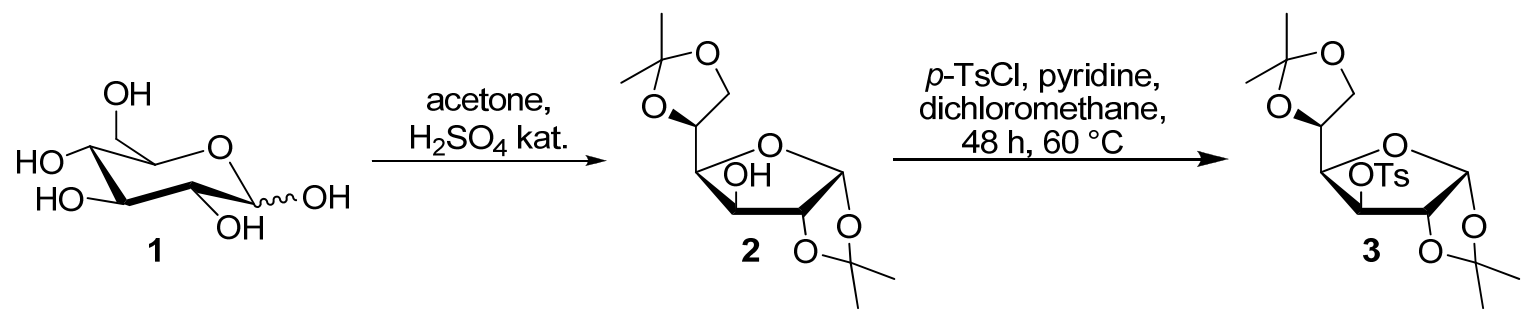

The crystal and instrumental parameters of the structure determination are summarized in Table 1. The drawing of the molecular structure of compound $\mathbf{3}$ with the used atom-labeling scheme is shown in Figure 2. The displacement thermal ellipsoids are drawn at the 30\% probability level. Selected bond lengths and angles comprising the key features of 1,2:5,6-di- $O$-isopropylidene-3- $O$-toluenesulfonyl- $\alpha$ D-glucofuranose (3) are given in Table 2.

Figure 2. A view of molecule 3 showing the atom-labeling scheme. Displacement ellipsoids are drawn at the $30 \%$ probability level.

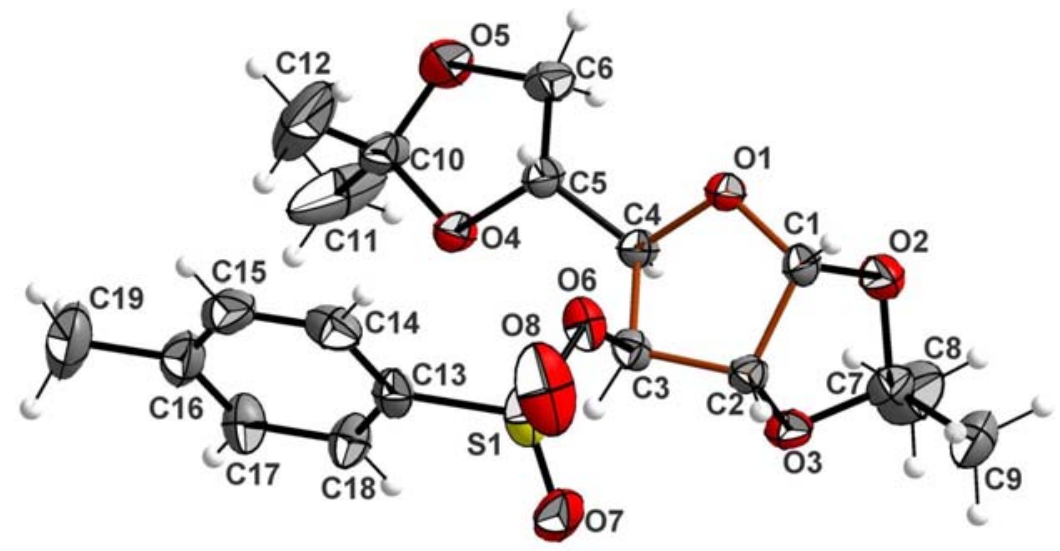


Table 1. Crystal data and structure refinement parameters for compound 3.

\begin{tabular}{|ll|ll|}
\hline \multicolumn{2}{|c|}{ Crystal data } & \multicolumn{2}{c|}{ Refinement } \\
\hline Formula & $\mathrm{C}_{19} \mathrm{H}_{26} \mathrm{O}_{8} \mathrm{~S}$ & Refinement method & $\begin{array}{l}\text { Full-matrix least- } \\
\text { squares on } F^{2}\end{array}$ \\
Formula weight & $414.48 \mathrm{~g} \cdot \mathrm{mol}^{-1}$ & & $6469 / 0 / 254$ \\
Temperature & $173(2) \mathrm{K}$ & Data/restraints/parameters & 18550 \\
Wavelength & $0.71073 \AA$ & Measured reflections & 1.032 \\
Crystal system & orthorhombic & Goodness-of-fit on $F^{2}$ & $R_{I}=0.0509$ \\
Space group & $\mathrm{P} 2{ }_{1} 2_{1} 2_{1}$ & Final $R$ indices & $w R_{2}=0.1238$ \\
Unit cell dimensions & $a=9.7945(7) \AA$ & {$[I>2 \sigma(I)]$} & $R_{I}=0.0660$ \\
& $b=10.1945(7) \AA$ & $R$ indices (all data) & $w R_{2}=0.1357$ \\
& $c=21.306(1) \AA$ & & $0.417 /-0.375 \mathrm{e} \AA^{-3}$ \\
Volume & $2127.4(2) \AA^{3}$ & Largest diff. peak/hole & \\
$Z$ & 4 & & \\
Density (calcd.) & $1.294 \mathrm{~g} \cdot \mathrm{cm}^{-3}$ & & \\
Absorption coefficient & $0.193 \mathrm{~mm}^{-1}$ & & \\
F(000) & 880 & & \\
Crystal size & $0.70 \times 0.22 \times 0.11 \mathrm{~mm}^{3}$ & & \\
\hline
\end{tabular}

Figure 3. View of two neighboring molecules in $\mathbf{3}$ with the shortest intermolecular contact drawn as a dashed line.

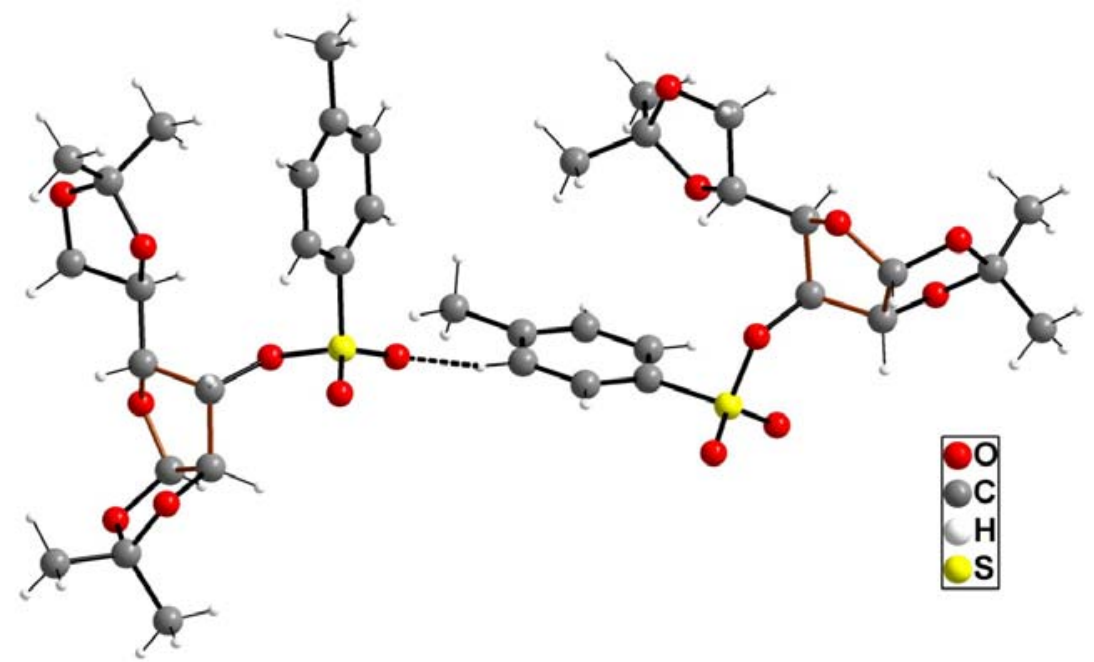

In the title compound, the conformation of the furanose ring is fixed by the two isopropylidene protecting groups. Each of the protecting groups form a five membered ring with the furanose skeleton. The first group is attached to $\mathrm{O} 2(\mathrm{C} 1)$ and $\mathrm{O} 3$ (C2), both carbon atoms have the R configuration. The second isopropylidene protecting group is attached to $\mathrm{O} 4$ (C5) and $\mathrm{O} 5$ (C6). The atom $\mathrm{C} 3$ has $\mathrm{S}$ configuration, whereas $\mathrm{C} 4$ is R-configured. The furanose ring has a distorted envelope conformation, in which $\mathrm{C} 1, \mathrm{C} 2, \mathrm{C} 3$ and $\mathrm{O} 1$ are located almost in a plane, and atom $\mathrm{C} 4$ is the one out of this plane. The $(\mathrm{C} 1, \mathrm{C} 2, \mathrm{C} 3, \mathrm{O} 1)$ plane has a dihedral angle of $35.5^{\circ}$ relative to the mean plane through $\mathrm{O} 1, \mathrm{C} 4$ and $\mathrm{C} 3$. Figure 2 shows, that atom $\mathrm{C} 11$, which is part of the isopropylidene group attached to $\mathrm{O} 4$ and O5, has an unusual ratio of the anisotropic displacement parameters. Attempts to use split positions did not improve the model. Therefore, it is concluded that the various energetically very close positions of 
this methyl group, as averaged over all the unit cells of the used crystal, are best described by a cigartype ellipsoid.

Between the molecules there are no classical hydrogen bonds, because all the O-bonded $\mathrm{H}$ atoms are substituted by protecting and leaving groups, respectively. The shortest intermolecular contact is between $\mathrm{O} 8$ and H14A (C14) of the neighboring molecule at an $\mathrm{O}-\mathrm{C}$ distance of 2.941(4) $\AA$. Figure 3 shows the two adjacent molecules with this short intermolecular contact.

Table 2. Selected interatomic distances $[\AA]$ in $\mathbf{3}$.

\begin{tabular}{|cc|cc|}
\hline atoms & distance & atoms & Distance \\
\hline $\mathrm{O} 1-\mathrm{C} 1$ & $1.439(2)$ & $\mathrm{S} 1-\mathrm{O} 7$ & $1.431(2)$ \\
$\mathrm{O} 1-\mathrm{C} 4$ & $1.407(2)$ & $\mathrm{S} 1-\mathrm{O} 8$ & $1.418(2)$ \\
$\mathrm{C} 1-\mathrm{C} 2$ & $1.518(2)$ & $\mathrm{S} 1-\mathrm{C} 1$ & $1.748(2)$ \\
$\mathrm{C} 2-\mathrm{C} 3$ & $1.526(2)$ & $\mathrm{C} 5-\mathrm{C} 6$ & $1.508(3)$ \\
$\mathrm{C} 3-\mathrm{C} 4$ & $1.538(2)$ & $\mathrm{C} 5-\mathrm{O} 2$ & $1.420(2)$ \\
$\mathrm{C} 1-\mathrm{C} 5$ & $1.506(3)$ & $\mathrm{C} 6-\mathrm{O} 3$ & $1.394(3)$ \\
$\mathrm{C} 2-\mathrm{O} 4$ & $1.451(2)$ & $\mathrm{C} 7-\mathrm{O} 2$ & $1.437(2)$ \\
$\mathrm{C} 3-\mathrm{O} 5$ & $1.415(2)$ & $\mathrm{C} 7-\mathrm{O} 3$ & $1.406(3)$ \\
$\mathrm{C} 4-\mathrm{O} 6$ & $1.406(2)$ & $\mathrm{C} 17-\mathrm{O} 5$ & $1.427(3)$ \\
$\mathrm{S} 1-\mathrm{O} 4$ & $1.588(2)$ & $\mathrm{C} 17-\mathrm{O} 6$ & $1.431(3)$ \\
\hline
\end{tabular}

\section{Experimental Section}

\subsection{General}

NMR spectra were recorded on a Varian Inova-400 spectrometer and chemical shifts of the ${ }^{1} \mathrm{H}$ and ${ }^{13} \mathrm{C}$ spectra were reported in parts per million (ppm) using the solvent shifts. The melting point was determined on a Galen III (Cambridge Instruments) melting point apparatus (Leica, Vienna, Austria) and is uncorrected.

\subsection{Synthesis of Compound 3}

1,2:5,6-Di- $O$-isopropylidene- $\alpha$-D-glucofuranose $(2.16 \mathrm{~g}, 8.3 \mathrm{mmol})$ was dissolved in pyridine $(20 \mathrm{~mL})$ and $p$-toluenesulfonyl chloride $(2.6 \mathrm{~g}, 13.6 \mathrm{mmol})$ dissolved in anhydrous dichloromethane $(20 \mathrm{~mL})$ was added at ambient temperature. The resulting mixture was stirred $48 \mathrm{~h}$ at $60{ }^{\circ} \mathrm{C}$. Afterwards, the organic solvents were removed, the residue was dissolved in dichloromethane $(20 \mathrm{~mL})$ and washed with saturated hydrogen carbonate solution $(20 \mathrm{~mL})$. The organic layer was separated and dried over $\mathrm{Na}_{2} \mathrm{SO}_{4}$. Purification was done via column chromatography (petroleum ether/ethyl acetate $=15: 1 \rightarrow 10: 1)$ to yield 3 as colourless solid $(2.68 \mathrm{~g}, 78 \%)$. m.p. $121{ }^{\circ} \mathrm{C} .{ }^{1} \mathrm{H} \mathrm{NMR}(400 \mathrm{MHz}$, $\left.\mathrm{C}_{6} \mathrm{D}_{6}\right): \delta 0.96\left(\mathrm{~s}, 6 \mathrm{H},{ }^{\mathrm{i}} \mathrm{Pr}-\mathrm{CH}_{3}\right), 1.10\left(\mathrm{~s}, 3 \mathrm{H},{ }^{\mathrm{i}} \mathrm{Pr}-\mathrm{CH}_{3}\right), 1.28\left(\mathrm{~s}, 3 \mathrm{H},{ }^{\mathrm{i}} \mathrm{Pr}-\mathrm{CH}_{3}\right), 1.82$ (s, 3H, Tos- $\left.\mathrm{CH}_{3}\right), 3.84$ (dd, $\left.{ }^{2} J=8.6 \mathrm{~Hz},{ }^{3} J=6.3 \mathrm{~Hz}, 1 \mathrm{H}, \mathrm{H}-6 \mathrm{~b}\right), 3.96\left(\mathrm{dd},{ }^{2} J=8.6 \mathrm{~Hz},{ }^{3} J=4.7 \mathrm{~Hz}, 1 \mathrm{H}, \mathrm{H}-6 \mathrm{a}\right), 4.07-4.12$ (m, $1 \mathrm{H}, \mathrm{H}-5), 4.25$ (dd, $\left.{ }^{3} J=8.0 \mathrm{~Hz},{ }^{3} J=2.8 \mathrm{~Hz}, 1 \mathrm{H}, \mathrm{H}-4\right), 4.90\left(\mathrm{~d},{ }^{3} J=3.6 \mathrm{~Hz}, 1 \mathrm{H}, \mathrm{H}-2\right), 5.02(\mathrm{~d}$, $\left.{ }^{3} J=2.8 \mathrm{~Hz}, 1 \mathrm{H}, \mathrm{H}-3\right), 5.66\left(\mathrm{~d},{ }^{3} J=3.6 \mathrm{~Hz}, 1 \mathrm{H}, \mathrm{H}-1\right), 6.67\left(\mathrm{~d},{ }^{3} J=8.2 \mathrm{~Hz}, 2 \mathrm{H}, \mathrm{H}-\mathrm{o}\right), 7.76(\mathrm{~d}$, $\left.{ }^{3} J=8.2 \mathrm{~Hz}, 2 \mathrm{H}, \mathrm{H}-\mathrm{m}\right) .{ }^{13} \mathrm{C}$ NMR $\left(101 \mathrm{MHz}, \mathrm{C}_{6} \mathrm{D}_{6}\right): \delta 21.1\left(\mathrm{Tos}_{-} \mathrm{CH}_{3}\right), 24.7,25.0,26.7\left(3 \times{ }^{\mathrm{i}} \mathrm{Pr}-\mathrm{CH}_{3}\right)$, $26.8\left({ }^{\mathrm{i}} \mathrm{Pr}-\mathrm{CH}_{3}\right), 67.4$ (C-6), 72.3 (C-5), 80.4 (C-4), 82.7 (C-3), 84.1 (C-2), 105.6 (C-1), 109.1, 112.3 $\left(2 \times{ }^{\mathrm{i}} \operatorname{Pr}-\mathrm{C}_{\text {quart }}\right), 128.8(\mathrm{C}-\mathrm{m}), 129.7$ (C-o), 133.8 (C-i), 144.5 (C-p). 


\subsection{Data Collection and Refinement}

Crystallographic data were collected with a Bruker-Nonius Apex-X8 CCD-diffractometer with

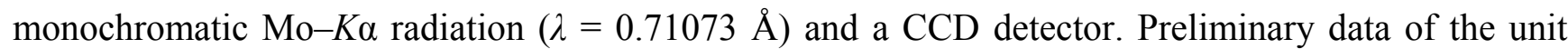
cell dimensions were obtained from the reflex positions of 36 frames, measured in three different directions of the reciprocal space. After completion of the data measurements the reflex intensities were corrected for Lorentz, polarization and absorption effects. The structure was solved by direct methods using SHELXS-97 and refined against $F^{2}$ on all data by full-matrix least-squares methods using SHELXL-97(2) [6,7]. All non-hydrogen atoms were refined anisotropically; all hydrogen atoms bonded to carbon atoms were placed on geometrically calculated positions and refined using riding models. Crystallographic data has been deposited with the Cambridge Crystallographic Data Centre, CCDC-855989. It can be retrieved free of charge through deposit@ccdc.cam.ac.uk or http://www.ccdc.cam.ac.uk.

\section{Conclusions}

The crystal and molecular structure of the title compound is reported. These data represent a crystallographically characterized example of tosylated carbohydrate building blocks.

\section{References and Notes}

1. Lindhorst, T.K. Essentials of Carbohydrate Chemistry and Biochemistry, 2nd ed.; Wiley-VCH: Weinheim, Germany, 2003.

2. Einhorn, C.; Luche, J.-L. Ready preparation of sugar acetals under ultrasonic irradiation. Carbohydrate Res. 1986, 155, 258-261.

3. Freudenberg, K.; Ivers, O. Synthesen gemischt-acylierter Halogen-zucker. Ber. Deut. Chem. Gesellsch. (A and B Series) 1922, 55, 929-941.

4. Boons, G.-J.; Hale, K. Organic Synthesis with Carbohydrates, 1st ed.; Sheffield Academic Press: Sheffield, UK, 2000.

5. Horton, D.; Roski, J.P.; Norris, P. Cycloaddition of Cyclopentadiene to 3-Deoxy-1,2:5,6-di-Oisopropylidene- $\alpha$-D-erythro-hex-3-enofuranose. Synthesis and Representative Chemistry of 1,6Anhydro-2,3-dideoxy- $\beta$-D-glycero-hex-2-enopyran-4-ulose ("Isolevoglucosenone"). J. Org. Chem. 1996, 61, 3783-3793.

6. Sheldrick, G.M. SHELXS/L-97, Programs for the Solution and Refinement of Crystal Structures; University of Göttingen: Göttingen, Germany, 1997.

7. Sheldrick, G.M. A short history of SHELX. Acta Cryst. 2008, A64, 112-122.

(C) 2012 by the authors; licensee MDPI, Basel, Switzerland. This article is an open access article distributed under the terms and conditions of the Creative Commons Attribution license (http://creativecommons.org/licenses/by/3.0/). 